\title{
HUBUNGAN ANTARA ADVERSITY QUOTIENTDAN SELF EFFICACY DENGAN MENGGUNAKAN MODEL PBL TERHADAP HASIL BELAJAR FISIKA SISWA SMA
}

\author{
Dian Sandi Pratama ${ }^{1}$, Imas Ratna Ermawaty ${ }^{2}$, dan Tri Isti Hartini ${ }^{3}$ \\ 1,2,3 Program Studi Pendidikan Fisika Universitas Muhammadiyah Prof. Dr. Hamka \\ Jl. Tanah Merdeka, Kp. Rambutan, Ciracas, Jakarta Timur, Indonesia

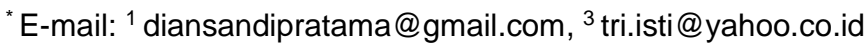

\begin{abstract}
Abstrak
Penelitian ini bertujuan untuk mengetahui hubungan antara Adversity Quotient dengan Hasil Belajar fisika siswa SMA, mengetahui hubungan antara Self Efficacy dengan Hasil Belajar fisika siswa SMA, serta mengetahui hubungan antara Adversity Quotient dan Self Efficacy dengan hasil belajar fisika siswa SMA. Berdasarkan hasil perhitungan regresi linier $Y$ atas $X_{1}$ diperoleh $\widehat{Y}=33,797+0,5505 X$ Dari hasil perhitungan ANAVA didapat $F_{\text {hitung }}$ $=0,117<F_{\text {tabel }}=2,28$. Hasil perhitungan regresi linier $Y$ atas $X_{2}$ diperoleh $\hat{Y}=30,061+0,5965 X$ dan hasil perhitungan ANAVA didapat $F_{\text {hitung }}=0,4681<F_{\text {tabel }}=2,28$. Sedangkan hasil perhitungan regresi linier $Y$ atas $X_{1}$ dan $X_{2}$ diperoleh $\widehat{Y}=43,52+\left(0,996 X_{1}\right)+\left(0,586 X_{2}\right)$ dan koefisien korelasi ganda $F_{h}=14,076>F_{t}(0,05: 2 / 31)=$ 3,32 . Pengujian hipotesis dilakukan dengan analisis korelasi ganda dan korelasi parsial didapat analisis korelasi $Y$ atas $X_{1}$ adalah thitung $>$ trabel yaitu 6,108 $>2,042$ yang berarti Ha diterima. Analisis korelasi $Y$ atas $X_{2}$ didapat thitung $>$ trabel yaitu 10,870 > 2,042 yang berarti Ha diterima, sedangkan analisis korelasi $Y$ atas $X_{1}$ dan $X_{2}$ diperoleh $F_{\text {hitung }}$ $=14,076>F_{\text {tabel }}=3,32$ yang berarti Ha diterima. Koefisien korelasi parsial $X_{1}$ dan $Y$ jika $X_{2}$ dikontrol diperoleh thitung $>$ tabel yaitu 2,640 $>2,042$ yang berarti Ha diterima, sedangkan koefisien korelasi parsial $X_{2}$ dan $Y$ jika $X_{1}$ dikontrol diperoleh thitung $>$ tabel yaitu 6,582 $>2,042$ yang berarti Ha diterima. Oleh karena itu, hasil penelitian ini dapat disimpulkan bahwa terdapat hubungan yang signifikan antara Adversity Quotient dan Self Efficacy dengan Hasil Belajar fisika siswa SMA.
\end{abstract}

Kata kunci: Adversity Quotient, Self Efficacy, Hasil Belajar.

\section{PENDAHULUAN}

Pada jenjang pendidikan menengah hingga atas, umumnya mata pelajaran fisika masih (saja) dianggap sulit bagi sebagian besar siswa. Hal ini pernah juga peneliti alami ketika peneliti berada pada masa-masa Sekolah Menengah Pertama (SMP), hingga Sekolah Menengah Atas (SMA). Anggapan tentang betapa sulitnya fisika disebabkan oleh beberapa faktor, salah satunya adalah banyak terdapatnya rumus dan hukum di dalamnya. Kesulitan-kesulitan tersebut kerap kali membuat siswa menjadi kehilangan semangat, menyebabkan kehilangan motivasi, sehingga siswa menjadi enggan mengerjakan soal-soal yang diberikan oleh guru, dan cenderung lebih memilih untuk mencontek. Atau lebih jauh lagi, dampak buruknya adalah hilangnya keyakinan siswa untuk mampu menguasai mata pelajaran fisika, dan bahkan dapat pula menyebabkan stres di kalangan siswa itu sendiri.

Melihat kondisi seperti yang telah dijabarkan di atas, sudah sepatutnya guru sebagai seorang pendidik harus memahami keadaan psikis dan non-psikis yang terjadi pada siswa-siswinya. Sehingga dapat mengetahui faktor-faktor yang menjadi permasalahan siswa dalam belajar, baik internal maupun eksternal. Permasalahan internal siswa dalam belajar dari fakor psikologis, yaitu antara lain intelegensi, motivasi, minat, bakat, percaya diri, dan kondisi stres.Di samping itu, untuk mendapatkan hasil belajar yang baik pula dibutuhkan daya juang siswa agar dapat meraih hasil yang maksimal. Ketangguhan dan daya juang inilah yang 
dikonseptualisasikan oleh Paul G. Stolz dalam Shen sebagai kecerdasan ketegaran daya juang atau disebut juga sebagai Adversity Quotient(AQ)[1].

Selain dari faktor Adversity Quotient $(A Q)$, untuk mencapai hasil belajar siswa sebagaimana yang diharapkan, dibutuhkan juga rasa percaya diri yang muncul dari keinginan dalam merepresentasikan keberhasilan yang diinginkan. Ada berbagai jenis dari kepercayaan diri yang ada pada manusia, salah satunya adalah Self Efficacy. Self Efficacy adalah evaluasi seseorang terhadap kemampuan atau kompetensinya untuk melakukan sebuah tugas, mencapai tujuan, atau mengatasi hambatan[2]. Rasa kepercayaan pada diri dan keyakinan akan keberhasilan akan usaha yang dilakukan untuk menjadi yang terbaik di kelas, setidaknya akan membuat siswa mengerahkan usaha yang lebih lagi, dan akan bertahan pada tugas yang ada meskipun itu sulit.

Dari hasil wawancara yang dilakukan terhadap siswa-siswi di SMA Negeri 32 di Jakarta Selatan, ternyata masih banyak siswasiswi yang tidak menyukai pelajaran fisika, mereka menganggap bahwa pelajaran fisika merupakan pelajaran yang sangat sulit dan penuh dengan rumus-rumus yang harus dihafal. Hal tersebut terlihat dari rendahnya tingkat pemahaham siswa terhadap konsepkonsep fisika, dan kurangnya keyakinan untuk dapat menyelesaikan soal-soal fisika yang diperlihatkan dengan banyaknya siswa yang belum mencapai Kriteria Kelulusan Minimal (KKM) yang di tetapkan oleh guru mata pelajaran fisika pada rekapitulasi ulangan harian 1, 2 dan 3 sebagai berikut:

Tabel 1. Rekapitulasi Nilai UHKelas XI MIA SMA Negeri 32 Jakarta Selatan

\begin{tabular}{|c|c|c|c|c|c|c|c|}
\hline \multirow[t]{2}{*}{ No } & \multirow[t]{2}{*}{ Kelas } & \multirow[t]{2}{*}{ Test } & \multirow[t]{2}{*}{ KKM } & \multicolumn{2}{|c|}{$\begin{array}{c}\text { Siswa yang } \\
\text { Memperoleh Nilai } \\
\text { Diatas KKM }\end{array}$} & \multicolumn{2}{|c|}{$\begin{array}{c}\text { Siswa yang } \\
\text { Memperoleh } \\
\text { Nilai Dibawah } \\
\text { KKM }\end{array}$} \\
\hline & & & & Jumlah & $\%$ & Jumlah & $\%$ \\
\hline \multirow{3}{*}{1} & \multirow{3}{*}{ XI MIA 1} & $\mathrm{UH} 1$ & 75 & 5 & 14,70 & 29 & 85,30 \\
\hline & & UH 2 & 75 & 11 & 32,36 & 23 & 67,64 \\
\hline & & $\mathrm{UH} 3$ & 75 & 6 & 17,65 & 28 & 82,35 \\
\hline \multirow{3}{*}{2} & \multirow{3}{*}{ XI MIA 3} & $\mathrm{UH} 1$ & 75 & 3 & 8,83 & 31 & 91,17 \\
\hline & & UH 2 & 75 & 7 & 20,59 & 27 & 79,41 \\
\hline & & $\mathrm{UH} 3$ & 75 & 8 & 23,53 & 26 & 76,47 \\
\hline
\end{tabular}

Berdasarkan permasalahan di atas, maka tujuan dari penelitian ini adalah untuk menunjukan dan membuktikan secara empiris bahwa terdapat hubungan antara Adversity Quotient (AQ) dan Self Efficacy (SE) secara bersama-sama dalam model pembelajaran berbasis masalah dengan hasil belajar Fisika siswa SMA Negeri 32 Jakarta.

Teknik penelitian yang digunakan dalam penelitian ini adalah teknik korelasional, yang dimaksudkan untuk mengetahui ada atau tidaknya hubungan antar variabel. Penelitian ini dilakukan pada seluruh siswa kelas XI MIA di SMAN 32 Jakarta sebagai Populasi terjangkau, dan kelas XI MIA-3 sebagai sampelnya.

\section{METODE}

Penelitian ini merupakan penelitian deskriptif kuantitatif dengan menggunakan desain penelitianPre-Experimental Design, pengambilan sampel menggunakan teknik Cluster Random Sampling dengan memilih sampel secara random bukan didasarkan pada individual atau anggota-anggotanya, tetapi lebih didasarkan pada kelompok daerah, atau kelompok subjek yang secara alami berkumpul bersama [3]. Dari kelas eksperimen diambil 34 siswa secara random sampling, dimana seluruh siswa diajar dengan menggunakan model pembelajaran Problem Based Learning. Jadi, pengambilan sampel dilakukan dengan cara multi stage random sampling. Setelah diberikan perlakuan, siswa diberikan instrumen skala sikap yang dipisahkan menjadi pernyataan favourable dan unfavourable, dan bertujuan untuk mengetahui tingkat $A Q$ dan $S E$ yang dimiliki oleh peserta didik. Lebih jauh lagi, hal ini juga bertujuan untuk mencari tahu seperti apa hubungan antara $A Q$ dan $S E$ terhadap hasil belajar siswa dalam hal ini adalah nilai pada mata pelajaran fisika.

Analisis data hasil penelitian meliputi analisis hasil instrument Adversity Quotient, Self Efficacy, dan Hasil Belajar dengan tahapan sebagai berikut:

a. Uji Prasyarat Analisis Data: 
1. Uji Normalitas menggunakan Lilliefors Galat Taksiranpada taraf signifikansi $\alpha$ $=0,05$

Jika Lnitung $<$ Ltabel berarti kelas berdistribusi normal

Jika Lnitung $>$ Ltabel berarti kelas tidak berdistribusi normal

2. $\cup \mathrm{ji}$ Homogenitas menggunakan $\mathrm{Uj \textrm {j }}$ Bartlettpada taraf signifikansi $\alpha=0,05$ Jika Xhitung $<X_{\text {tabel }}$ berarti kelas bersifat homogen

Jika Xhitung $>$ Xtabel berarti kelas bersifat tidak homogen

3. Uji Linieritas dengan mencari persamaan regresi dan menggunakan metode kuadrat terkecilpada taraf signifikansi $\alpha=0,05$

$H_{0}=Y=a+b X$ berarti model regresi berpola linier

$H_{0}=Y \neq a+b X$ berarti model regresi berpola tidak linier

b. Analisis Korelasi

1. Koefisien korelasi ganda $Y$ atas $X_{1}$ dan $\mathrm{X}_{2}$ pada taraf signifikansi $\alpha=0,05$

Jika $F_{\text {Hitung }} \leq F_{\text {Tabel }}$ maka tidak terdapat hubungan yang signifikan

Jika $F_{\text {Hitung }}>\mathrm{F}_{\text {Tabel }}$ maka terdapat hubungan yang signifikan

2. Koefisien korelasi parsial antara $Y$ dan $X_{2}$ jika $X_{1}$ dikontrolpada taraf signifikansi $\alpha=0,05$

Jika - ttabel $\leq \mathrm{t}_{\text {Hitung }} \leq \mathrm{t}$ tabelmaka

tidak terdapat hubungan yang signifikan

Jika thitung > tTabel maka Homaka terdapat hubungan yang signifikan

3. Koefisien korelasi parsial antara $Y$ dan $\mathrm{X}_{1 j \mathrm{jika}} \mathrm{X}_{2}$ dikontrolpada taraf signifikansi $\alpha=0,05$

Jika $-\mathrm{t}_{\text {tabel }} \leq \mathrm{t}_{\text {Hitung }} \leq \mathrm{t}_{\text {Tabelmaka }}$

tidak terdapat hubungan yang signifikan

Jika tHitung $_{\text {}}$ t $_{\text {Tabel }}$ maka Homaka terdapat hubungan yang signifikan

c. Uji Hipotesis

$\mathrm{H}_{0}: \rho=0$ artinya:
1. Diduga tidak terdapat hubungan yang signifikan antara Adversity Quotient dengan hasil belajar fisika siswa

2. Diduga tidak terdapat hubungan yang signifikan antara Self Efficacy dengan hasil belajar fisika siswa

3. Diduga tidak terdapat hubungan yang signifikan antara $A Q$ dan $S E$ dengan hasil belajar fisika siswa

$\mathrm{H}_{0}: \rho \neq 0$ artinya:

1. Diduga terdapat hubungan yang signifikan antara Adversity Quotient dengan hasil belajar fisika siswa

2. Diduga terdapat hubungan yang signifikan antara Self Efficacy dengan hasil belajar fisika siswa

3. Diduga terdapat hubungan yang signifikan antara $A Q$ dan $S E$ dengan hasil belajar fisika siswa

\section{HASIL DAN PEMBAHASAN}

Secara terperinci, data hasil perhitungan uji prasyarat dapat dilihat pada tabel-tabel berikut ini:

a. Uji Normalitas

Tabel 2. Uji Normalitas $A Q$ dan $S E$

\begin{tabular}{|c|c|c|c|c|c|}
\hline No. & Variabel & $(\boldsymbol{\alpha})$ & $\mathbf{L}_{\text {bitungl }}$ & $\mathbf{L}_{\text {Tabel }}$ & Keterangan \\
\hline 1. & Advertisy Quotient & 0,05 & 0,1356 & 0,1519 & Normal \\
\hline 2. & Self Efficacy & 0,05 & 0,0700 & 0,1519 & Normal \\
\hline
\end{tabular}

b. Uji Homogenitas

Tabel 3. Uji Homogenitas $A Q$ dan SE

\begin{tabular}{|c|c|c|c|c|c|}
\hline No. & Variabel & $\boldsymbol{( \alpha )}$ & $\chi_{\text {Hitung }}$ & $\chi_{\text {Tahel }}$ & Keterangan \\
\hline 1. & Advertisy Quotient & 0,05 & 8,927 & 27,586 & Homogen \\
\hline 2. & Self Efficacy & 0,05 & 3,930 & 26,296 & Homogen \\
\hline
\end{tabular}

Setelah data terdistribusi Normal dan Homogen, maka kemudian tahap selanjutnya adalah menguji signifikansi dan linieritas dari persamaan regresi Hasil Belajar dengan Adversity Quotient dan Hasil Belajar dengan Self Efficacy menggunakan ANAVA dua jalur. 
Tabel 4. Uji Signifikansi dan Linieritas Hasil Belajar dan $A Q$

\begin{tabular}{|c|c|c|c|c|c|}
\hline $\begin{array}{c}\text { Sumber Varians } \\
\text { (SV) }\end{array}$ & Dk & JK & RJK & FHitung & F Tabel \\
\hline Total & 34 & 169479 & - & & \\
\cline { 1 - 4 } Regresi (a) & 1 & 168300,3 & 16300,3 & & \\
\cline { 1 - 4 } Regresi (b/a) & 1 & 207,9 & 207,9 & \multirow{2}{*}{0,9817} & \multirow{2}{*}{2,25} \\
\hline Residu & 32 & 970,8 & 34,67 & & \\
\hline Tuna Cocok & 16 & 411,63 & 25,726875 & & \\
\cline { 1 - 3 } Kesalahan (Error) & 18 & 559,17 & 31,065 & & \\
\cline { 1 - 3 }
\end{tabular}

Catatan : $F_{\text {Tabel }}$ ditetapkan untuk $\alpha=0,05$

Tabel 5. Uji Signifikansi dan Linieritas Hasil Belajar dan SE

\begin{tabular}{|c|c|c|c|c|c|}
\hline $\begin{array}{l}\text { Sumber Varians } \\
\text { (SV) }\end{array}$ & Dk & JK & RJK & FHitung & $\mathrm{F}_{\text {Tabel }}$ \\
\hline Total & 34 & 169479 & - & \multirow{6}{*}{1,9846} & \multirow{6}{*}{2,26} \\
\hline Regresi (a) & 1 & 168300,3 & 16300,3 & & \\
\hline Regresi (b/a) & 1 & 164,7 & 164,7 & & \\
\hline Residu & 32 & 1014 & 36,21 & & \\
\hline Tuna Cocok & 15 & 570,125 & 38,00833333 & & \\
\hline Kesalahan (Error) & 19 & 443,875 & 29,59166667 & & \\
\hline
\end{tabular}

Catatan : $F_{\text {Tabel }}$ ditetapkan untuk $\alpha=0,05$

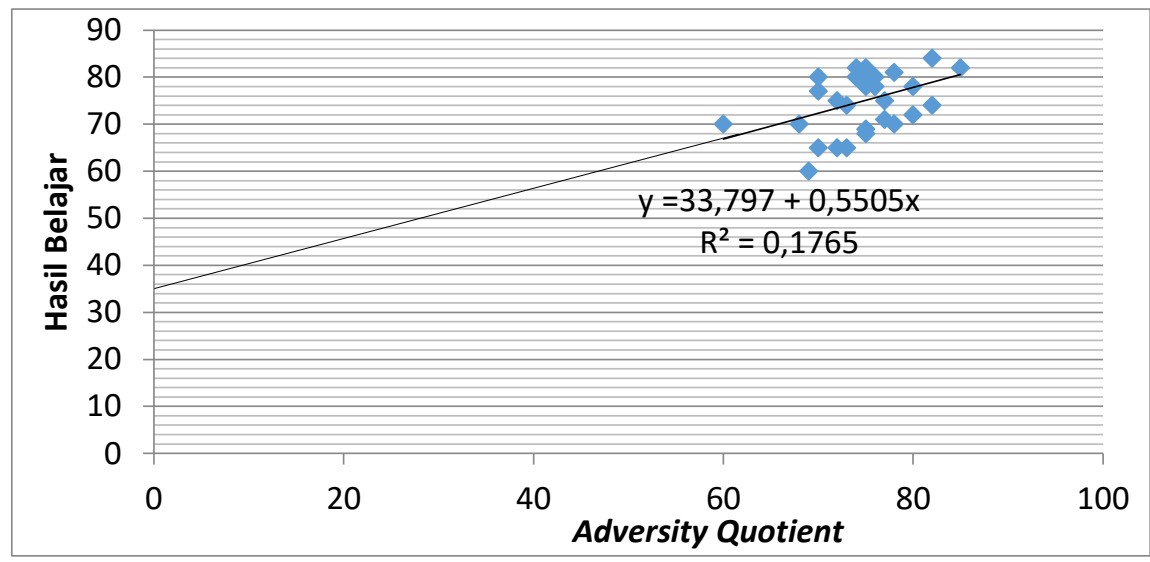

Gambar 1. Grafik Persamaan Regresi Antara Hasil Belajar dan $A Q$ 
Grafik 2. Grafik Persamaan Regresi Antara Hasil Belajar dan SE

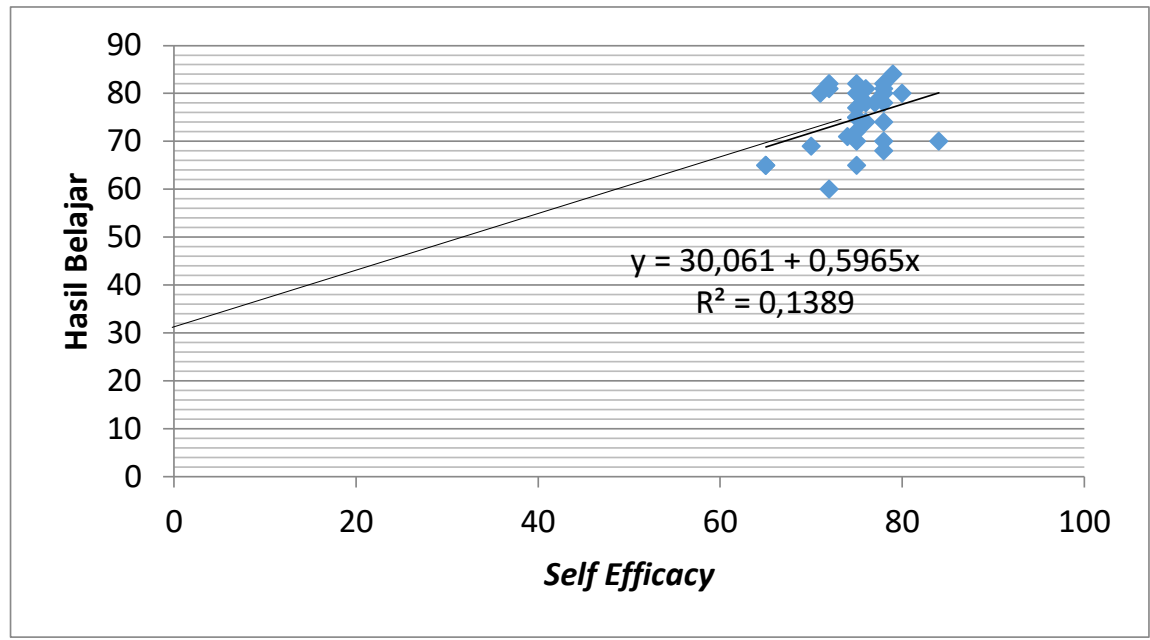

Langkah selanjutnya adalah pengujian hiotesis dengan analisis korelasi, pengujian ini bertujuan untuk mengetahui apakah hipotesis yang telah dirumuskan dapat terbukti secara empiris sehingga hipotesis dapat diterima atau bahkan ditolak.

Tabel 6.Pengujian Hipotesis Korelasi Ganda $Y$ atas $\mathrm{X}_{1}$ dan $\mathrm{X}_{2}$

\begin{tabular}{|c|c|c|c|c|}
\hline $\begin{array}{c}\text { Korelasi } \\
\text { Antara }\end{array}$ & $\begin{array}{c}\text { Koefisien } \\
\text { Korelasi }\end{array}$ & \multicolumn{2}{|c|}{$\begin{array}{c}\text { Koefisi Chart Area } \\
\text { Determinasi }\end{array}$} & - Fitung \\
\hline $\mathrm{X}_{1} \mathrm{X}_{2}$ dan $\mathrm{Y}$ & 0,846 & $71,57 \%$ & 34,076 & 3,32 \\
\hline
\end{tabular}

Berdasarkan tabel 6. di atas, pengaruh keberadaan $A Q$ dan $S E$ secara bersama-sama terhadap Hasil belajar didapatkan nilai persentase sebesar $71,57 \%$, sedangkan sisanya ditentukan oleh variabel lain. Setelah mengetahui hubungan antar variabel, selanjutnya adalah mencari tingkat keeratan hubungan suatu variabel independent dengan variabel dependent menggunakan korelasi parsial.

1. Koefisien Korelasi Parsial Antara $Y$ dan $X_{2}$ Jika $X_{1}$ Dikontrol

Tabel 7. Koefisien Korelasi Parsial Antara $Y$ dan $\mathrm{X}_{2}$ Jika $\mathrm{X}_{1}$ Dikontrol

\begin{tabular}{|c|c|c|c|c|}
\hline Korelasi Antara & $\boldsymbol{\alpha}$ & $\mathbf{d k}$ & $\mathbf{t}_{\text {Hitumg }}$ & $\mathbf{t}_{\text {Tabel }}$ \\
\hline $\begin{array}{c}\text { Y dan } \mathrm{X}_{2} \text { Jika } \mathrm{X}_{1} \\
\text { dikontrol }\end{array}$ & 0,025 (two tail) & 31 & 6,582 & 2,042 \\
\hline
\end{tabular}

Karena thitung $>$ tabel $(0,025 ; 31)$ yaitu $6,582>$ 2,042 maka pengujian hipotesis menolak $\mathrm{H}_{0}$ dan menerima $\mathrm{H}_{\mathrm{a}}$

2. Koefisien Korelasi Parsial Antara $\mathrm{Y}$ dan $\mathrm{X}_{1}$ Jika $\mathrm{X}_{2}$ Dikontrol
Tabel 8. Koefisien Korelasi Parsial Antara $Y$ dan $\mathrm{X}_{1}$ Jika $\mathrm{X}_{2}$ Dikontrol

\begin{tabular}{|c|c|c|c|c|}
\hline Korelasi Antara & $\boldsymbol{\alpha}$ & $\mathbf{d k}$ & $\mathbf{t}_{\text {Hitung }}$ & $\mathbf{t}_{\text {Tabel }}$ \\
\hline $\begin{array}{c}\text { Y dan } \mathrm{X}_{1} \text { Jika } \mathrm{X}_{2} \\
\text { dikontrol }\end{array}$ & 0,025 (Two Tail) & 31 & 2,640 & 2,042 \\
\hline
\end{tabular}

Karena thitung $>$ tabel $(0,025 ; 31)$ yaitu 2,640 > 2,042 maka pengujian hipotesis menolak $\mathrm{H}_{0}$ dan menerima $\mathrm{H}_{\mathrm{a}}$

\section{PENUTUP}

Secara garis besar, kesimpulan pada penelitian ini dapat dijelaskan menjadi:

1. Terdapat hubungan yang signifikan antara adversity quotient dengan hasil belajar dengan nilai thitung $=6,108>$ tabel $(0,025 ; 32)=$ 2,042 pada taraf signifikansi nilai $a=0,05 / 2$.

2. Terdapat hubungan yang signifikan antara self efficacy dengan hasil belajar dengan nilai thitung $=10,870>$ tabel $(0,025 ; 32)=2,042$ dengan taraf signifikansi nilai $a=0,05 / 2$.

3. Terdapat hubungan yang signifikan antara adversity quotient dan self efficacy dengan hasil belajar dengan nilai $F_{\text {hitung }}=34,076$ dan $F_{\text {tabel }}=3,35$ dengan taraf signifikansi $a=$ 0,05 dengan $\mathrm{dk}_{\text {pembilang }}=2$ dan $\mathrm{dk}_{\text {penyebut }}=34$ $-2-1=31$

\section{UCAPAN TERIMAKASIH}

Penulis mengucapkan terima kasih kepada berbagai pihak yang telah membantu dalam penulisan artikel ini. Penelitian ini didanai oleh Dra. Imas Ratna Ermawati, M.Pd 
dan juga Dr.(Can) Tri Isti Hartini, M.Pd.

\section{DAFTAR PUSTAKA}

Bandura, A., \& Self-efficacy In, V. S. (1994). Ramachaudran (Ed.), Encyclopedia of Human Behavior, 4, 71-81. Academic Press. New York., (Reprinted in H. Friedman[Ed.], Encyclopedia of mental health. San Diego. Academic Press. (1998).

Darmadi, H. (2011). Metode penelitian pendidikan. Alfabeta: Bandung.

Robert, A. B., \& Byrne, D. (2004). Psikologi Sosial Edisi kesepuluh. Jakarta: Erlangga.

Shen, C. Y. (2014). A Study Investigating the Influence of Demographic Variables on Adversity Quotient. The Journal of Human Resource and Adult Learning, 10(1), 22-32.

Shivaranjani. .(2014). Adversity Quotient: One Stop Solution to Combat Attrition Rate of Women in Indian it Sector. International Journal of Business and Administration Research Review, 1(5), 182-189

Stoltz, P. G. (2005). Adversity Quotient (Alih Bahasa: T. Hermaya). Grasindo. Jakarta. 